\title{
THE HUMAN RIGHTS BETWEEN MORALS AND POLITICS: ON JÜRGEN HABERMAS'S COSMOPOLITANISM
}

\author{
OS DIREITOS HUMANOS ENTRE A MORAL E A POLÍTICA: SOBRE O \\ COSMOPOLITISMO DE JÜRGEN HABERMAS
}

\author{
LUIZ REPA ${ }^{1}$ \\ (USP, Brazil)
}

\begin{abstract}
:
The aim of this paper is to show some tensions of Habermasian project about cosmopolitanism. First, it shall show that the cosmopolitan right is not based on a moral conception but in normative grammar of right itself, which only found a developed institutional reality in the framework of the national state. Secondly, it seeks to show that the need for a European identity, required by Habermas, clashes with other concepts developed by the philosopher to overcoming the national identity. Finally, it shall demonstrate that the cosmopolitan project by Habermas is thought as a sort of phasing in, so that it sticks to the EU program and sets aside other possibilities for cosmopolitanism.
\end{abstract}

Key words: Cosmopolitanism. Human rights. Popular sovereignty. Politics. Morals.

Brazil has been targeted by the politics of the human rights for quite a long time. The international intergovernmental or nongovernmental organizations tirelessly denounce the country's precarious situation regarding the defense of the fundamental rights since the process of overture and democratization, mainly concerning the police brutality and the conditions of the Brazilian prison system. Nevertheless, to this situation, which has achieved some improvement in recent years, a new circumstance which seemed possible to take place only in the most advanced European countries and in the United States - and that frequently harms the Brazilian emigrants - has been added lately. Clandestine immigrants, especially Bolivians, find themselves, due to their illegal condition, totally unprotected and submitted to all sorts of humiliating coercions, as slave work, for instance.

Despite this aggravation, a certain trend of suspicion regarding the policy of human rights in the Brazilian political thinking does not seem to have been deeply changed, both to the left and to the right. As soon as the question of how effectively to protect the human rights of citizens and noncitizens is posed, for their violation is often protracted by the State or is 
allowed for several reasons due to the omission of the State, the moral sympathy for the "pariahs" and the "derelicts" fades into the defense of the principle of national sovereignty.

At best, one defends that it is only through democracy that the means and the legitimate basis for a successful implementation of human rights may occur, even though they are already provided in the law in accordance with the Constitution as a matter of fundamental rights or in accordance with the several international treaties of support to the human rights, of which Brazil is often a signatory. The most suitable answer for the demands of the politics of the human rights would not properly be an enhancement of the law, but rather an accomplishment of the law by means of democratization, so that the principle of selfdetermination might be preserved.

It remains unnoticed, though, the fact that the systematic disrespect to the human rights parallels the voluntary or no voluntary respect for international agreements in the economic area which reduced, since the late eighties, the margins of action of some sort of independent politics of development. Despite the recent relative success of the BRICS grouping in comparison to the countries which were at the core of the 2008 crisis, one cannot disregard that the globalization decreased and truly affected the political autonomy of almost the whole world, perhaps with the strong exception of the United States and China. Thus, the extolled principle of self-determination, in what concerns the politics of human rights, must coexist with a realistic view according to which capitalism has reduced the possibilities of the democracy and the national State of solving problems which, in their turn, often create the conditions denounced by the politics of human rights.

By rights, it is not a paradox, since both of them can be situated in different levels: a properly normative level and a more descriptive one. But to the ones who intend to mingle these two levels, Jürgen Habermas's “cosmopolitan" political thinking may sound at least appealing from a philosophical point of view - even though the most important institutional arrangement he has foreseen, the European transnational democracy, seems to be very far. It is worth remarking that Habermas has introduced his thinking on the cosmopolitan right, almost invariably, from the point of view of the safeguard and the effectiveness of the popular sovereignty; we might add, from a perspective which tries to respond to the postnational condition which has undermined democracies all over the world. It is, as Pauline Kleingeld quickly states, a “more clearly political” cosmopolitanism (KLEINGELD, 1999, p.505).

On the other hand, it is also worth mentioning the fact that Habermas does not extend the idea of transnationalization of democracy beyond the European borders - as much as he 
defends the protection of the human rights by a worldwide organization - generates miscomprehension on the normative status he confers to this sort of rights. Thus, it seems that Habermas oscillates between a politico-juridical foundation of the human rights which is suggested by his strategy of starting everything by the democratization of the European Union and a moral foundation of the human rights which is introduced every time similar conditions to the ones offered by the European Union lack. Such moral foundation seems not only to retroact to the first step but also to free the project from a sort of paternalistic cosmopolitan politics, ruled by the democratic Western societies - which means, by some European countries, as the Brazilian sociologist Sérgio Costa denounces, in virtue of Habermas's defense of the military intervention in Kosovo (COSTA, 2006, p. 46).

I will attempt to support here that Habermas does not yield to a strictly moral foundation of the human rights, even though the moral point of view still plays an important role in them; from this refusal, on the other hand, one should not infer, as some cosmopolitans argue, that Habermas is still attached to a conception of democracy which is connected to the tradition of the national State (FINE; SMITH, 2003). Certainly, there is some ambivalence concerning the civil solidarity required by the transnational democratization, but this ambivalence should not obliterate the fact that the discourse theory breaks with the normative framework provided by the nation-state. The discourse theory upon which the Habermasian approach of cosmopolitanism is supported denies the idea that a former collective identity is always required for the establishment of solidarity nets. Thus, I shall argue that the ambivalence of the Habermasian cosmopolitanism is due to a sort of phasing in, whose initial stage might only be the European Union. It is in this sense that one may say that Habermas is stuck to the model of the national State, i.e., to the national State's political model of development, out of which he thinks the European process of unification. The "realistic" perspective Habermas intends to confer to cosmopolitanism induces him to idealize Europe and to lose sight of other promising possibilities to cosmopolitanism which emerge out of the European project nowadays.

In many senses, the cosmopolitan project introduced by Kant stands as a challenge for Jürgen Habermas's political thinking. The Kantian project is interpreted by Habermas from the idea of constitutionalization of the international law aiming at guaranteeing the rights of the individuals, regardless of their belonging to the national States, even becoming able to lay legal claims against these States. He adds to that the idea of some sort of worldwide internal politics without worldwide government which should be able to deal with the several socio- 
economic imbalances of an uneven worldwide society, but, above all, with the imposition of the human rights and the guarantee of peace.

In a normative sense, Habermas must somehow reconcile the cosmopolitan law, understood as a law applicable to every individual and thus fitted with typically juridical mechanisms, with a foundation, within the framework given by the modern national state, of the fundamental rights by means of the discourse theory. The peculiar strategy adopted for this foundation is worth mentioning.

Its main content lies in the idea that there is a logical co-originality between the fundamental rights which guarantee the private autonomy and the political rights which constitute the sense of the popular sovereignty. One does not go without the other, contrarily to what the traditions of liberalism and republicanism have intended in their own ways, Kant and Rousseau included, the ones who got closer to the idea of co-originality. In liberalism altogether and in Kant - our main concern by now -, in a particular way, it is the moral foundation of the subjective rights of equal freedoms of action which is mainly criticized, since thus operating, the political legislators limit themselves to state positively a set of rules given in advance to the process of deliberation. This subordination of the rights to the morals is seen by Habermas as premodern in its structure and, in addition, leads to a paternalism of the Rule of Law in relation to the citizens. Thus, Habermas states that "Nothing is given prior to the citizen's practice of self-determination" (HABERMAS, 1998, pp.127-8), other than the discourse principle and the legal medium as such; therefore, a procedure of legitimation and a formal principle of structuring norms, but not a set of norms, whatever nature they might have. On the other hand, the subjective rights which guarantee the private autonomy may not be set in such a way they are at the legislator's disposal, thus, the political autonomy is also affected: the ones who can take part in the process of political formation of the opinion and of the will must have the required independence to leave the political public space, as well. Furthermore, there is not right itself without that set of subjective rights. Therein lies Habermas's peculiarity in comparison to the liberal tradition or the whole philosophy of law perhaps: the juridical form itself implies the rights of liberty, independently of a moral ground. Otherwise, the law would not be able to have its coercive character as a fundamental property: one may not coerce those who do not have freedom of action and freedom of will. Withal, a form of norms which makes it possible for a negative space of freedom to exist and is directed by nature to the external coercion cannot be morally grounded. 
On the other hand, the subjective rights must be configured and politically positivized. If they are immanent to the juridical form as such, their concrete configuration must be set by means of the citizen's political autonomy. In the public space formed by the political rights, therefore, moral discourses for grounding the content of the fundamental rights unfold beside ethical-political discourses related to the concrete values of a certain political collectivity. Thus, a moral basis of the fundamental rights emerges from within the process of deliberation, for, due to their claim for universal validity, these fundamental rights present themselves as human rights.

Therefore, concerning the debate on whether the human rights are originally moral or juridical, Habermas undoubtedly chooses the second option:

\footnotetext{
The conception of human rights does not have its origins in morality; rather, it bears the imprint of the modern concept of individual liberties and is therefore distinctly juridical in character. What gives human rights the appearance of being moral rights is neither their content nor even their structure but rather their form of validity, which points beyond the legal order of the nation-state" (HABERMAS, 1997, p. 137).
}

In other words, the human rights are primarily basic subjective rights, without them a juridical order in the modern sense is not possible, i.e., it is characterized at once by liberties of action to be fulfilled according to each one's free-will as well as connected to a power of coercion. Nevertheless, the constitutional texts refer to them as "innate" - which means that they are paradoxically positivized as innate. This feature, typical of the historical declarations of the human rights, is primarily due to the fact that they are not at the legislator's disposal, thus, otherwise, a juridical medium by means of which one may legislate cannot be constituted. The fundamental rights form, as Klaus Günther states, is a grammar of legislation; a grammar which the legislator must regulate though. In this proper political level, one is required to ground these subjective rights. It is in this regard that they seem to correspond to moral norms. For the sense of their validity is not restricted to the members of a political-juridical collectivity, although one may guarantee them, in governmental grounds, only to the members. In other words, the juridical validity is universal, even if the execution is limited to the space constituted by the political collectivity. One may not think that a fundamental right might be grounded and solely attributed on behalf of one's belonging to a collectivity. As, for instance, that the right to life may be claimed and safeguarded only to 
these or those peoples, even if only a member of these or those peoples may lay legal claim to this right.

Thus, the universal validity of the fundamental rights coincides with the universal validity of the moral norms. That is the reason why in the scope of the regulation of the matters of rights of liberty, as well as the social rights, the strictly moral arguments may suffice for grounding, whereas for the other juridical categories, ethical-political and pragmatic arguments also intervene. That is, in the case of the rights of liberty and welfare, the legislator may recur to moral arguments in order to give reasons why the rules expressed by those rights are good for everyone.

From this moral grounding, nevertheless, it does not follow that any identification between fundamental rights and moral norms may be traced, insofar as the first ones keep their juridical properties: they dissociate any subjective right from moral duties, conceding to the legal subject a morally undetermined, negative space of action. And, it is worth stressing, these juridical properties cannot be morally grounded or, moreover, cannot be normatively grounded anyhow, so that the juridical form remains a mechanism for social integration for which there are not any alternatives in modernity.

Nevertheless, Habermas adds one more reason to the fact that there is a conflation of fundamental rights with moral norms:

\footnotetext{
The mistake of conflating them with moral results from their peculiar nature: apart from their universal validity claims, these rights have had an unambiguously positive form only within the national legal order of the democratic state. Moreover, they possess only weak validity in international law, and they await institutionalization within the framework of a cosmopolitan order which is only now emerging (HABERMAS, 1997, p. 140).
}

This account is curious. What leads to the conflation of moral with right is the fact that the institutionalization of the fundamental rights is still precarious or even absent outside the national State. Thus, its validity claim is only met in this framework, seeming to become a merely moral requirement beyond the borders of the state. If the positive law is absent, there it comes the morals.

However, is it in fact possible to talk about non-institutionalized rights in a juridical sense? For Habermas, as one may notice, the cosmopolitan institutionalization of the fundamental rights only complies with the universal validity which concerns this juridical 
category, which, in its turn, has already accomplished a relatively robust institutionalization only in the national level of law. Yet, as this same institutionalization demonstrates that such rights are not originally moral, beyond the national level, it remains not a moral demand in the proper sense, but the coherent institutional development of the validity of the fundamental rights. It is always the same kind of right in the several areas of what Kant named public law. Thus, one may say that the cosmopolitan right is the culmination of a universalistic logic which is inherent to the fundamental right in its strictly juridical character.

On the other hand - inasmuch as this universalistic element is a condition of possibility of popular sovereignty, which crystallizes itself in the framework of the national State, resulting, in its turn, in the fundamental rights themselves - there seems to be some tension between the universalistic right and the ever particularistic democracy, or else, some tension between the universal claim of right and its particular accomplishment. This tension (or ambivalence) has not remained unnoticed by some critics, according to whom the Habermasian cosmopolitanism tends to be mitigated - what is particularly at stake here is the refusal of the idea of a worldwide democracy - because the philosopher is still attached to the conceptual framework provided by the nation-state. Thus, if Robert Fine and Will Smith recognize that Habermas "presents cosmopolitanism as the logical culmination of the principles of right", they quickly add that he is very "cautious about breaking the connection between democracy and the nation-state", i.e., he conceives of democracy in such a way that “it can hardly be approached in the cosmopolitan level” (FINIS; SMITH, 2003, pp. 470, 473$5)$.

In fact, it is surprising that Habermas writes the following in his decisive essay on the postnational constellation and the future of democracy - a passage which is often criticized by the most radical cosmopolitans:

The world organization] is distinguished from state-organized communities by the principle of complete inclusion - it may exclude nobody, because it cannot permit any social boundaries between inside and outside. Any political community that wants to understand itself as a democracy must at least distinguish between members and non-members. The self-referential concept of collective selfdetermination demarcates a logical space for democratically united citizens who are members of a particular political community. Even if such a community is grounded in the universalist principles of a democratic constitutional state, it still forms a collective identity, in the sense that it interprets and realizes these principles in light of its own history and in the context of its own particular form of life. This ethicalpolitical self-understanding of citizens of a particular democratic life is missing in the inclusive community of world citizens. (HABERMAS, 2001, p. 107) 
If, on the one hand, Habermas emphasizes the universalistic character of the fundamental rights which signalize beyond the borders of the national state, on the other, he underlines the particularism of the democratic interpretation of these very rights, which is determined by the belonging to a community in particular and by a certain collective identity. Now, this restriction of the cosmopolitan democracy ends up contradicting not only the cooriginality between human rights and popular sovereignty - for the aspired institutionalization of the fundamental rights qua cosmopolitan rights is independent of a worldwide democratization - but also contradicts a great part of the arguments Habermas supports in favor of the European Union's democratization. For, in this context, Habermas resorts to the nation-state not to confirm the only "logical space" for political self-determination, but, to the contrary, to prove the possibility of widening this "place" even more, independently of a previously formed identity. The notion of constitutional patriotism as well, which must be able to substitute nationalism as a source of civil solidarity, is structured in such a manner upon abstract principles that it is hard to see the reason why it should be limited to the national or European borders. Inversely, the constitutional patriotism goes together with a desubstantialization, with a proceduralization of the popular sovereignty whose first outcome is exactly to take away from the people the marks of an inclusion or exclusion of principles, only remaining the determination of being a member or not.

It is hard to figure out the reason why Habermas suffers from this sudden Schmittian attack or, at best, a Hegelian attack, as if a worldwide democracy would only be conceptually possible due to the presence of a non-man people, as an invasion of extraterrestrials representing the "other", the non-member. If, from the beginning, I stressed the Habermasian criticism to liberalism in virtue of the refusal of subordinating the right to morals, which would mean to previously delimit the autonomy of the political legislator, I must now emphasize that a similar criticism may be directed to republicanism in general, and to Rousseau in a particular sense: a previous consensus based on the ethos of a given community is refused by Habermas due to the same reasons as well. It means that Rousseau would not have been properly radical in his conception of unlimited sovereignty. Strictly speaking, for Habermas, there must not be a people in order to the people's sovereignty may be constituted. It is normatively reduced to the democratic principle according to which "only [...] may claim legitimacy [the juridical law] that can meet with the assent (Zustimmung) of all citizens in a 
discursive process of legislation that in turn has been legally constituted" (HABERMAS, 1998a, p. 110).

Surely, such a discursive procedure must be able to take into account ethical-political discourses concerning which sets of values are exemplary for the political collectivity, but all that managed in such a way that the juridical conditions of the procedure are not affected, i.e., without prejudice to the juridical equality and liberty individually taken. Precisely because they are submitted to the discursive processes, collective values, whatever origins they may have, tend to suffer a desubstantialization, whose outcome is exactly an opening to the other (i.e., the other from a different culture, which nonetheless may be a co-citizen).

It is not a matter of minimizing the importance of civil solidarity, especially concerning its role of supporting the risks of a political redistribution of goods. However, from the normative baseline given by Habermas with the idea of co-originality between human rights and popular sovereignty, this civil solidarity presents itself as far more created, out of the enlargement of democracy, than presupposed as given beforehand. One may not forget to consider here an insight from the discourse theory and the deliberative democracy which is underexplored, including by Habermas himself, but which did not go unnoticed by Richard Sennet: that the discussion and the disagreement may bring the participants closer in the sense of creating solidarity bonds than the affirmation of common values (SENNET, 1999, p. 172).

It is also important to notice that Habermas approaches the nation-state from the perspective provided by Benedict Anderson (ANDERSON, 1983), according to whom a nation is above all an imagined community, constructed in many different ways, often departing from the State in order to reach the nation (as in the Brazilian case, for instance). The artificial, constructed character of the nation-state would then act in favor of a widening of the civil solidarity beyond the national borders, in favor of a sort of European solidarity. Nevertheless, it would only be possible by means of political anticipations for the development of the democratic process - and it is within this process that the civil solidarity which is crystallized around the idea of constitutional patriotism, both in the national and European levels, seems to be grounded.

Now, the idea of constitutional patriotism as a substitute for nationalism makes sense mainly in a multicultural environment, where the idea of nationality loses the concrete reference, even if imaginary, to an origin. But in this case, for Habermas, it reflects less a one 
and the same reaffirmation of a character than the disposition of interpreting the constitutional principles from the point of view of the others:

\begin{abstract}
A liberal political culture is only the common denominator for a constitutional patriotism (Verfassungspatriotismus) that heightens an awareness of both the diversity and the integrity of the different forms of life coexisting in a multicultural society. [...] One' s own tradition must in each case be appropriated from a vantage point relativized by the perspectives of other traditions [...]. A particularist anchoring of this kind would not do away with one iota of the universalist meaning of popular sovereignty and human rights (HABERMAS, 1996, p. 500).
\end{abstract}

Such understanding of the constitutional patriotism, which keeps the universalistic sense of the human rights within the multiplicity of cultural interpretations which are open to one another, seems to make the collective identity even more subtle; for Habermas, this sort of identity would be required in order to project the cosmopolitan democracy, but that would be accessible only in the European framework. For, this identity would mean, in the light of the constitutional patriotism, the respect for otherness and a defense of juridical and political principles which assert exactly such respect, i.e., everything that leads to the inclusion of the other, rather than a demarcation in relation to the other.

Altogether, one may say that the Habermasian distrust in relation to the possibilities of a cosmopolitan democracy, concerning the conditions of a political collectivity, ends up in conceptions which make this collectivity rather porous, not to say abstract, so that it is difficult to understand, eventually, the reason why one may distrust of the possibility of the cosmopolitan democracy. If democracy is capable of creating or at least recreating the sources of civil solidarity among strangers, then the crux of the matter is less in the collective identity, which is presumed to have always been artificial and constructed, than in the first steps towards democratization and, with it, into the worldwide juridical configuration of the human rights, a process which might create itself solidarity nets spread beyond the national borders.

As problematic as this appeal to a collective identity, which has little particular concreteness in the end, seems to be the premise which grounds all the Habermasian diagnosis on cosmopolitanism and the postnational condition, namely, the premise according to which cosmopolitanism will really have a chance if the European Union advance some steps towards its political unity. Habermas goes on saying that what is utopian in the cosmopolitan project is exactly the absence of other "Unions" in different regions of the globe ${ }^{2}$. 
Thus he proposes a view of the cosmopolitan project as dependent upon a progress towards a growing regional transnationalization, for which, nevertheless, only the European Union stands as a concrete example. Everything happens as if the political units were supposed to incorporate themselves into the increasingly larger ones so that the proper condition for a reform of the UN - aiming at the implementation of a global internal politics, i.e., the overcoming, by each member, of the idea of sovereignty according to the model of national sovereignty - would take place. It is this gradual learning process of surpassing its own sovereignty that Habermas imputes to the development - still unaccomplished and full of disturbances - of the constitutionalization of the European Union, for which other examples in the world still lack.

For Habermas, Europe is the only example of it for various reasons. Though, the most important of them are connected to the commonplace diagnosis of that time centered in the expression "postnational constellation". This diagnosis basically consists of the occurrence of a sort of democratic deficit within the economic globalization and, therefore, together with it, a deficit of legitimation of the organisms which create political determinations that affect the national context of contemporary society. In the Habermasian vocabulary, a new overlapping of systemic imperatives with the life-world takes place, despite that not even the systemic mechanisms have a legitimate basis in the life-world. The immediate political translation of this diagnosis means that the popular sovereignty finds itself prevented from being carried out. Thus, the postnational constellation means above all a threat to democracy. While creating new social and political conflicts with the dissolution of a great deal of institutional structures of the national State that might give room to popular sovereignty, the postnational constellation resulting from the pressure of globalization hinders the management of these matters within the national compass. With the States' loss of competence, some blanks which become fulfilled by organisms based in agreements of the international public law are opened. The most appealing example of this transference of competence is the loss of financial sovereignty which took place in the European Union area with the introduction of euro as the common currency and with the independent European Central Bank, thus denationalizing the monetary policy. Basically, Habermas sees in these new intergovernmental organs, nondemocratic, functional responses - or, at least, without the democratic legitimation required to the risks that the globalization itself poses in every field and whose treatment requires international cooperation. Thus, the globalization also results in a worldwide society systemically produced; a society characterized by huge social inequalities among the different 
regions as well as inside every region and, at the same time, kept under the constant threat of ecological catastrophes.

Withal, Habermas considers that returning to the national State democracy is impossible under a systemic point of view, because it would mean pushing the internationalization of the economic means of reproduction back by force - a force which is inexistent within the scope of the national State itself. Besides, it would also be undesirable since it can mean an upsurge of nationalisms. Thus, the only way politics can cope with economics again is exactly by means of the transnationalization of democracy, which implies putting the popular sovereignty back again beyond the traditional and historical boundaries of the nation-state.

This last aspect is worth stressing, since one of the criticisms that seem to have gained notoriety against Habermas's cosmopolitan project refers to the ideological function it might perform for the consolidation of a hegemonic domination intrinsically bound together with the economic globalization. What lies behind the demand for an increasing juridification of the international relations, as Habermas aims, would be the attempt to restrict every country's national sovereignty, be it in Europe or in the rest of the world, asserting a policy of human rights and of a solely Western democracy, thus consolidating some sort of cultural hegemony of the West over the East, of the North over the South. An author that stands out in this matter is certainly the sociologist of law Danilo Zolo (ZOLO, 1999). Unlike Habermas, Zolo proposes a minimal political order in the international level, without having any international authoritative source ascribed to intervene in the national sovereignty, unless in particularly exceptional cases.

As I see it, the fulcrum of Haberma's project is not the liquidation of the national sovereignty, but the critical assumption that, nowadays, it is sovereignty itself, in its more democratic sense, as the self-determination of a political collectivity, which is being restricted by the economic globalization. The transference of sovereignty does not have to mean the end of popular sovereignty, although it may move from the state organization to the supranational organization. This displacement has been already carried out, without any legitimation, but precisely that of the national States.

Nevertheless, the excessive emphasis Habermas gives to the agony of the European democracies reveals an important feature of his diagnosis: it is in Europe, where the process of transference of sovereignty is accelerated, where the political effects of transnational administrative restrictions are more immediate, that, at the same time, the treaties signed by 
now point to the possibility of an effective democratization of the European Union. Thus, in one of his latest books, Habermas declares that "the European Union of the Lisbon Treaty is not as far removed from the form of a transnational democracy" (HABERMAS, 2012, p. 3), once it confers primacy to the European law over the national law, even though the EU does not hold the monopoly of violence. Besides, the treaty seems to confer the constituent power of the European Union exclusively to the citizens, considered as members of the Union as well as of the member State.

However, it is worth insisting in this particular manner of thinking of the conditions of possibility of cosmopolitanism from the European unification. Herein Habermas seems to be stuck to the example provided by the national State, since it would represent a progressive incorporation of political units, overcoming the local community belongings. But there is a series of debilities in transposing this model of political development into the register of cosmopolitanism. One of them is obvious: several European States, as Spain and Belgium, reveal that their national units are way more fragile than what they are supposed to be. On the other hand, perhaps the greatest weakness is of theoretical order: to get to cosmopolitanism, a gradual political integration is required on the model of nationalization, because it would mean learning to overcome the local sovereignties.

And again it seems to be possible to resort to the model of democracy supported by Habermas to think of another framework in which cosmopolitanism loses its somewhat ethereal character. Anyway, that would mean abandoning a sort of Eurocentrism and giving attention to the fact that the hegemonic centers have lost part of their strength, that several governmental and non-governmental actors have emerged, that the multilateralism supported by these new actors can be much more advantageous to the development of the politics of human rights than a new, at once supranational and national giant. The more this multilateralism is capable of imposing itself in the globalization environment which affects all at the same time, more and more the central idea that the democracy and the fundamental rights have less to do with an identity, with a sovereign "we", than with the freedom and the autonomy which must be imputed to every individual in a public sphere of discussion and deliberation, may gain strength. 
Notes:

${ }^{1}$ Luiz Repa is professor of Theory of Human Sciences at the University of São Paulo (USP), São Paulo, Brazil and researcher at the Centro Brasileiro de Análise e Planejamento (CEBRAP). He has researched on Critical Theory, especially the thought of Jürgen Habermas. In this research about this philosopher and social theorist, he has stressed the method of reconstruction and its relations with his political thought. E-mail: luizrepa@uol.com.br

2 "A reform of the United Nations, however successful, would remain ineffectual unless the nation-states in the various world regions come together to form continental regimes on the model of the European Union. For the moment, only modest steps have been taken in this direction. Herein, and not in the reform of the UN, lies the genuinely utopian moment of a "cosmopolitan condition" (HABERMAS, 2004, p. 107; 2006, p. 109). 


\section{Referências:}

ANDERSON, B. Imagined communities. Londres: Verso, 1983.

COSTA, Sérgio. Dois Atlânticos: teoria social, anti-racismo, cosmopolitismo. Belo Horizonte: UFMG, 2006.

FINE, Robert \& SMITH, Will. Jürgen Habermas's Theory of Cosmopolitanism. Constellations: an International Journal of Critical and Democratic Theory. Vol. 10, No 4, 2003.

HABERMAS, Jürgen. Faktizität und Geltung. Frankfurt am Main: Suhrkamp, 1992.

Kants Idee des ewigen Friedens - aus dem historischen Abstand Von 200 Jahren”. In: Die Einbeziehung des Anderen. Frankfurt am Main: Suhrkamp, 1996.

Kant's Idea of Perpetual Peace, with the Benefit of Two Hundred Years' Hindsight. In: BOHMAN, James \& LUTZ-BACHMANN, Matthias (eds) Perpetual Peace: Essays on Kant's Cosmopolitan Ideal. Cambridge, MA: MIT Press, 1997.

Between facts and norms. Massachusetts: MIT Press, 1998a.

"Die postnationale Konstellation und die Zukunft der Demokratie". In: Die postnationale Konstellation. Frankurt am Main: Suhrkamp, 1998b.

"The Postnational Constellation and the Future of Democracy". In: The postnational constellation: political essays. Cambridge, Massachusetts The MIT Press, 2001.

"Ein Interview über Krieg und Frieden". In: Der gespaltene Westen. Frankfurt am Main, Suhrkamp, 2004. Press, 2006.

An Interview on War and Peace. In: The divided west. Cambridge: Polity

The Crisis of the European Union: A Response. Cambridge: Polity Press, 2012a.

Sobre a constituição da Europa. São Paulo: UNESP, 2012b.

KLEINGELD, Pauline. Six Varieties of Cosmopolitanism in Late Eighteenth-Century Germany. Journal of the History of Ideas, vol. 60, n³ (Jul., 1999).

SENNETT, R. A corrosão do caráter. Rio de Janeiro: Record, 1999.

The Corrosion of Character: The Personal Consequences of Work in the New Capitalism. London/New York: W. W. Norton \& Co., 1998. 
ZOLO, D. A Cosmopolitan Philosophy of International Law? A Realist Approach. Ratio Juris, Vol. 12, No. 4, December 1999. 